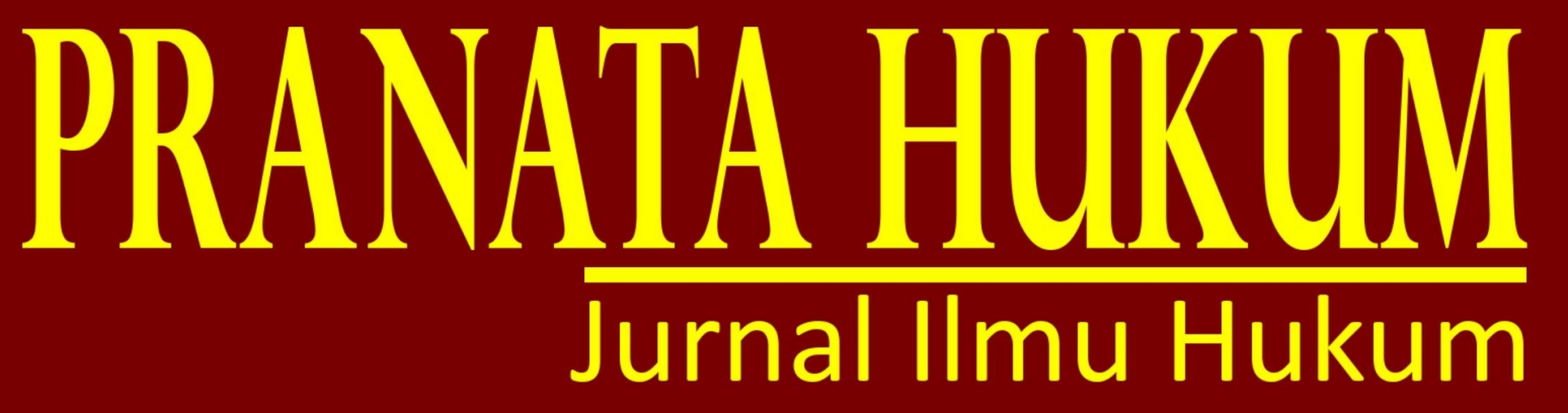

e-ISSN 2685-3213 | p-ISSN 1907-560X

EFEKTIVITAS ASEAN CONVENTION ON COUNTER TERRORISM DI DALAM MEMBERANTAS PEMBAJAKAN DI WILAYAH PERAIRAN ASIA TENGGARA

Rafi Darajati, Muhammad Syafei

PERLINDUNGAN HUKUM PENGGUNA JALAN DARI ANGKUTAN UMUM ONLINE PADA PENGGUNAAN TELEPON SAAT MENGEMUDI KENDARAAN

Rissa Afni Martinouva

ANALISIS PERTANGGUNGJAWABAN PELAKU TINDAK PIDANA MELAKUKAN PENEBANGAN POHON DALAM KAWASAN HUTAN TANPA IJIN YANG BERWENANG

Sukoco SP, Erlina B , Eddy S Wirabhumi

PERLINDUNGAN HUKUM PASIEN PADA BIDAN PRAKTIK MANDIRI DI INDONESIA PASCA DIKELUARKANNYA UNDANG-UNDANG NOMOR 4 TAHUN 2019 TENTANG KEBIDANAN Aditia Arief Firmanto

FUNGSI PENGAWASAN PERADILAN TATA USAHA NEGARA TERHADAP PERBUATAN PEMERINTAH PASCA UNDANG-UNDANG NOMOR 30 TAHUN 2014 TENTANG ADMINISTRASI PEMERINTAHAN Muhammad Rusjana

PELAKSANAAN PENGADAAN BARANG/JASA PEMERINTAH DITINJAU DARI PERPRES NOMOR 16 TAHUN 2018 TENTANG PENGADAAN BARANG/JASA PEMERINTAH DI KANTOR PERTANAHAN KOTA BANDAR LAMPUNG Aryana Wisastra, Baharudin, Indah Satria

KEWAJIBAN TANGGUNG JAWAB SOSIAL PERUSAHAAN (CORPORATE SOCIAL RESPONSIBILITY) DI INDONESIA: ANTARA LEGAL OBLIGATION ATAU MORAL OBLIGATION

Dani Amran Hakim, Dania Hellin Amrina

IMPLEMENTASI PERATURAN MENTERI AGRARIA DAN TATA RUANG/KEPALA BADAN PERTANAHAN NASIONAL NOMOR 13 TAHUN 2017 TENTANG TATA CARA BLOKIR DAN SITA PADA KANTOR PERTANAHAN KOTA BANDAR LAMPUNG

Sholin Erbin M Rajagukguk, Lintje Anna Marpaung, Herlina Ratna Sumbawa Ningrum

PEMBERIAN PATEN OBAT-OBATAN DAN PEMENUHAN HAK ASASI MANUSIA TERHADAP KESEHATAN DI INDONESIA

Chandra Muliawan

\begin{tabular}{c|c|c|c|c|}
\hline $\begin{array}{c}\text { PRANATA } \\
\text { HUKUM }\end{array}$ & $\begin{array}{c}\text { Volume } \\
14\end{array}$ & $\begin{array}{c}\text { Nomor } \\
\mathbf{2}\end{array}$ & $\begin{array}{c}\text { Halaman } \\
96-222\end{array}$ & $\begin{array}{l}\text { Bandar } \\
\text { Lampung } \\
\text { Juli 2019 }\end{array}$ \\
\hline
\end{tabular}




\section{PRANATA HUKUM}

Jurnal Ilmu Hukum

Magister Hukum

Universitas Bandar Lampung

Terbit Pertama Kali, Juli 2006

Terbit Dua Kali Setahun, Setiap Januari dan Juli

PENANGGUNG JAWAB

Rektor Universitas Bandar Lampung

KETUA PENYUNTING

Prof. Dr. Lintje Anna Marpaung, S.H., M.H

WAKIL KETUA PENYUNTING

Dr. Bambang Hartono, S.H., M.Hum

PENYUNTING PELAKSANA

Dr. Tami Rusli, S.H., M.Hum

Dr. Erlina B, S.H., M.H

Dr. Zainab Ompu Jainah, S.H., M.H

Indah Satria, S.H., M.H

Yulia Hesti, S.H., MH

\section{PENYUNTING AHLI (MITRA BESTARI)}

Prof. Dr. I Gusti Ayu Ketut Rachmi Handayani, S.H., M.M (Universitas Sebelas Maret) Prof. Dr. I Gede A.B Wiranata, S.H., M.H (Universitas Lampung) Dr. Nurhadiantomo, S.H., M.Hum (Universitas Muhammdiyah Surakarta) Dr. Erina Pane, S.H., M.H (UIN Lampung)

Alamat:

Kampus B Universitas Bandar Lampung

J1. Z.A Pagar Alam No.89 Labuhan Ratu, Bandar Lampung 35142

Telp: 0721-789825 Fax: 0721-770261

Email: jurnal.mh@ubl.ac.id 


\title{
KEWAJIBAN TANGGUNG JAWAB SOSIAL PERUSAHAAN (CORPORATE SOCIAL RESPONSIBILITY) DI INDONESIA: ANTARA LEGAL OBLIGATION ATAU MORAL OBLIGATION
}

\author{
Dani Amran Hakim¹, Dania Hellin Amrina ${ }^{2}$
}

\begin{abstract}
Corporate Social responsibility is the corporate social responsibility of the Community and the environment beyond economic responsibility. Corporate Social Responsibility is initially based on ethical and moral values, i.e. the company is considered unethical when enjoying great gains, while the environment is broken and the community is ignored or harmed by its rights. The implementation of CSR in Indonesia began at the time of Law No. 40 year 2007 about the limited liability company. However, the implementation of the CSR stipulated in Article 74 Act No. 40 year 2007 concerning the limited liability company shall cause inconsistency with the preceding provisions, as stipulated in article 1 Figure 3 of Law No. 40 year 2007 on Limited liability company. This is seen from the difference of basic concept to the social responsibility of the original social responsibility (moral obligation), as stated in article 1 Number 3 UUPT, become legal obligation (legal obligation) in article 74 Law number 40 year 2007 about the limited liability company. In addition, no provisions on sanctions for those who do not implement CSR in Law No. 40 year 2007 about the limited liability company also provide legal uncertainty in the implementation of CSR.
\end{abstract}

Keywords: Company, legal obligation, Corporate Social Responsibility.

\section{PENDAHULUAN}

Perkembangan dunia usaha yang semakin cepat dan meningkatnya persaingan, menuntut perusahaan untuk semakin meningkatkan kinerjanya. Keberadaan perusahaan ditengah-tengah masyarakat dan lingkungannya dapat memberikan citra yang positif dan negatif. Di satu sisi, perusahaan menyediakan barang dan jasa yang diperlukan oleh masyarakat, namun di sisi lain tidak jarang masyarakat dan lingkungan mendapatkan dampak buruk dari aktivitas perusahaan.

1 Dosen Fakultas Syari'ah, Universitas Islam Negeri Raden Intan Lampung, daniamranhakim@ radenintan.ac.id

${ }^{2}$ Dosen Fakultas Ekonomi dan Bisnis Islam Universitas Islam Negeri Raden Intan Lampung, daniahellin@gmail.com 
Hubungan yang baik antara perusahaan dengan masyarakat dan lingkungannya tentu dapat terwujud jika masyarakat dan lingkungan memiliki citra yang positif mengenai perusahaan yang bersangkutan. Citra yang positif ini bisa di bentuk apabila perusahaan memiliki sikap kepedulian. Saat ini berkembang sikap kepedulian perusahaan itu menjadi sebuah kegiatan dengan istilah tanggung jawab sosial perusahaan atau Corporate Sosial Responsibility (CSR).

Tanggung jawab sosial perusahaan atau yang lebih dikenal dengan Corporate Social Responsibility (CSR) pertama kali dicetuskan di Amerika Serikat, awalnya adalah upaya untuk melindungi buruh. Namun seiring perjalanan waktu definisi CSR berkembang menjadi suatu tanggung jawab sosial perusahaan terhadap perkembangan ekonomi, buruh karyawan, komunitas lokal, lingkungan sekitar dan masyarakat pada umumnya. Secara terminologis CSR belum memiliki pengertian tunggal yang dapat di generalisir, masih terdapatnya perbedaan pendapat tentang pengertian maupun konsepnya oleh para ahli.

Sampai pada dekade 1980-1990an, gagasan CSR terus berkembang. Lahirnya KTT Bumi di Rio pada 1992 menegaskan konsep sustainibility development (pembangunan berkelanjutan) sebagai hal yang mesti diperhatikan, tak hanya oleh negara, tapi terlebih oleh kalangan perusahaan. Tekanan KTT Rio, terasa bermakna sewaktu James Collins dan Jerry Porras melakukan penelitian yang berjudul Built To Last; Succesful Habits of Visionary Companies di tahun 1994. Lewat riset yang dilakukan, mereka menunjukkan bahwa perusahaan-perusahaan yang terus hidup bukanlah perusahaan yang hanya mencetak keuntungan semata. (Wisnu Darmadi, http://wisnu.blog.uns.ac.id /2009/11/26/corporate-socialresponsibility/kepedulian-perusahaan-terhadap-lingkungan-di-sekitarnya/.html)

Secara terminologi pengertian dan konsep Corporate Social Responsibility adalah tanggung jawab sosial terhadap masyarakat dan lingkungan di luar tanggung jawab ekonomis, atau komitmen perusahaan atau dunia bisnis untuk berkontribusi dalam pengembangan ekonomi yang berkelanjutan dengan memperhatikan tanggung jawab sosial perusahaan dan menitikberatkan pada keseimbangan antara perhatian terhadap aspek ekonomi, sosial, dan lingkungan. (Hendrik Budi Untung, 2009:1). Jika kita berbicara tentang tanggung jawab sosial perusahaan, maksudnya adalah kegiatan-kegiatan yang dilakukan perusahaan demi suatu tujuan sosial dengan tidak memperhitungkan untung atau rugi ekonomis.

Perkembangan pelaksanaan CSR di Indonesia ditandai dengan sudah banyak perusahaan menerapkan CSR. Perusahaan semakin banyak menerapkan CSR baik dalam bentuk amal (charity) maupun pembedayaan (enpowerment). Setidaknya bisa dilihat dari gencarnya publikasi berkait dengan implementasi CSR di media cetak dan elektronik. Merujuk kepada pemahaman yang digunakan dalam ISO 26000 yang secara konsisten mengembangkan tanggung jawab sosial, maka masalah CSR akan mencakup 7 isi pokok yaitu: a) Pengembangan masyarakat; b) 
Konsumen; c) Praktek kegiatan industri yang sehat; d) Lingkungan; e) Ketenagakerjaan; f) Hak azasi manusia; g) Organisasi pemerintah. ISO 26000 menjadi kunci penting untuk mendorong CSR yang subtansial dan komprehensif. (ISO 26000: Guidance Standard on Responsibility).

Berdasarkan amanah Pasal 1 ayat (3) Undang-Undang Dasar Negara Republik Indonesia Tahun 1945 menentukan bahwa Negara Indonesia adalah negara hukum. Negara Indonesia adalah Negara berdasar atas hukum, tidak berdasar atas kekuasaan dan pemerintahan berdasarkan konstitusi bukan absolutisme. (Satjipto Rahardjo, 2006: 240). Azas negara hukum, berarti dalam penyelenggaraan negara, tindakan penguasanya harus didasarkan hukum, bukan didasarkan kekuasaan atau kemauan penguasanya belaka dengan maksud untuk membatasi kekuasaan penguasa dan bertujuan melindungi kepentingan masyarakatnya, yaitu perlindungan dari tindakan sewenang-wenang. (Juniarso Ridwan dan Achmad Sodik Sudrajad, 2012: 25).

Negara hukum yang menjamin adanya tertib hukum dalam masyarakat artinya memberi perlindungan hukum pada masyarakat, yaitu antara hukum dan kekuasaan ada hubungan timbal balik, (Juniarso Ridwan dan Achmad Sodik Sudrajad, 2012: 25). sehingga terciptanya tatanan hidup berbangsa dan bernegara yang dinamis serta hukum menjadi panglima dan menjadi pedoman dalam menjalankan kehidupan sosial setiap warga negara. Maka dari itu untuk menjamin kepastian hukum dalam pelaksanaan CSR di Indonesia pemerintah mengeluarkan kebijakan berupa peraturan perundang-undangan yang mengatur mengenai CSR yang diharapkan nantinya dapat dijadikan pedoman dalam penerapannya.

\section{PEMBAHASAN}

Berlakunya Undang-Undang Nomor 40 Tahun 2007 tentang Perseroan Terbatas (UUPT), pada dasarnya merupakan suatu kebutuhan yang cukup mendesak bagi kalangan pengusaha sebagai pelaku usaha dan pemerintah sebagai pihak regulator di bidang usaha karena undang-undang perseroan terbatas yang sebelumnya berlaku sudah dianggap tidak relevan lagi dengan perkembangan dunia usaha. Secara garis besar terdapat beberapa perubahan signifikan dalam substansi undang-undang perseroan terbatas, salah satunya adalah terkait pengaturan tentang CSR atau yang dalam UUPT disebut dengan istilah "Tanggung Jawab Sosial dan Lingkungan Perusahaan".

Pengaturan CSR tidak terlepas hanya pada UUPT saja, namun ada juga Peraturan Pemerintah yang mengatur mengenai pelaksanaan CSR, yaitu Peraturan Pemerintah Nomor 47 Tahun 2012 tentang Tanggung Jawab Sosial dan Lingkungan Perusahaan. Peraturan Pemerintah ini adalah Peraturan Pemerintah yang dibuat oleh pihak eksekutif yang ditetapkan oleh Presiden yang dijadikan dasar hukum dalam pelaksanaan tanggung jawab sosial dan lingkungan, isinya mengatur mengenai pengertian-pengertian shareholders (para pemegang saham) 
dan mengatur mengenai bagaimana pelaksanaan dan penyelenggaraan tanggung jawab sosial dan lingkungan pada suatu perusahaan.

Berdasarkan PP No. 47 Tahun 2012 Pasal 2 menentukan bahwa, "Setiap Perseroan selaku subjek hukum mempunyai tanggung jawab sosial dan lingkungan". Kemudian Pasal 3 ayat (1) PP No. 47 Tahun 2012, disebutkan bahwa: "Tanggung jawab sosial dan lingkungan sebagaimana dimaksud dalam Pasal 2 menjadi kewajiban bagi Perseroan yang menjalankan kegiatan usahanya di bidang dan/atau berkaitan dengan sumber daya alam berdasarkan Undang-Undang". Jadi apabila merujuk pada Pasal ini bahwa terdapat ekstensi/perluasan makna kata, bahwa bukan hanya perusahaan yang melakukan kegiatan usaha yang berkaitan dengan sumber daya alam saja yang mempunyai kewajiban melaksanakan tanggung jawab sosial dan lingkungan namun setiap perseroan selaku subjek hukum juga mempunyai kewajiban dalam melaksanakan tanggung jawab sosial dan lingkungan.

Kemudian ayat (2) disebutkan bahwa: "Kewajiban sebagaimana dimaksud pada ayat (1) dilaksanakan baik di dalam maupun di luar lingkungan Perseroan". Jadi sudah jelas bahwa dalam melaksanakan tanggung jawab sosial dan lingkungan dilakukan baik di dalam perusahaan maupun di luar perusahaan. Pelaksanaan CSR diharapkan dapat memberikan sumbangan terhadap perbaikan sosial maupun lingkungan masyarakat, salah satu prinsip penting dalam CSR adalah pertanggungjawaban (responsibility) yang mengarah bukan hanya kepada shareholders tetapi kepada stakeholders dan kini ketentuan hukum positif mengatur bahwa CSR bukan lagi hanya merupakan pertanggungjawaban tetapi sudah merupakan kewajiban hukum (liability).

Corporate Social Responsibility pada awalnya dilandasi oleh nilai etika dan moral, kerena perusahaan dipandang tidak etis bila menikmati keuntungan yang besar, sementara lingkungan rusak dan masyarakat diabaikan atau dirugikan hakhaknya. Sesuai dengan inti dari kekuatan moral adalah kesadaran yang datang dari dalam diri perusahaan, ternyata tidak mampu menciptakan kesadaran perusahaan untuk peduli terhadap masyarakat dan lingkungan, oleh sebab itu hukum masuk dan menjadikan CSR sebagai suatu yang wajib bagi perusahaan. Beberapa ahli dan kalangan usaha memandang moral dan hukum terkait CSR dalam pendekatan yang dikotomis, padahal keduanya bisa saling bersinergi dan saling mengisi. (Daniel T. Ostas, 2001:272).

Berdasarkan Pasal 1 butir 3 UUPT menyebutkan Tanggung Jawab Sosial dan Lingkungan adalah komitmen Perseroan untuk berperan serta dalam pembangunan ekonomi berkelanjutan guna meningkatkan kualitas kehidupan dan lingkungan yang bermanfaat, baik bagi Perseroan sendiri, komunitas setempat, maupun masyarakat pada umumnya. Selain itu dasar hukum penerapan CSR diatur juga dalam aturan turunan dari UUPT, yaitu PP No. 47 Tahun 2012. Dengan demikian telah menjadi kewajiban hukum bagi perusahaan dalam menerapkan 
CSR perusahaanya. Penerapan CSR merupakan salah satu penerapan prinsip Good Corporate Governance (GCG) yang berkaitan dengan tanggung jawab sosial perusahaan kepada publik. (Muh Arief Effendi http://wwwsuarakaryaonline.com/news.html?id).

Hubungan CSR dengan Good Corporate Governance adalah merupakan suatu sistem dan seperangkat peraturan yang mengatur hubungan antar berbagai pihak yang berkepentingan. Terutama dalam arti sempit, yakni hubungan antara pemegang saham dan dewan komisaris serta dewan direksi demi tercapainya tujuan perusahaan. Dalam arti luas, yaitu mengatur seluruh kepentingan stakeholders agar dapat diakomodir secara proporsional. GCG juga, dimaksudkan untuk memastikan bahwa kesalahan-kesalahan dalam strategi perusahaan dapat diperbaiki dengan segera.

Menurut J.S Badudu dan Sutan Mohammad Zain, penerapan adalah hal, cara atau hasil. (Yus Badudu dan Sultan Muhammad Zain. 1994: 1497). Adapun menurut Lukman Ali, penerapan adalah mempraktekkan, memasangkan. (Lukman Ali, 1995:1044). Berdasarkan pengertian tersebut dapat disimpulkan bahwa penerapan merupakan sebuah tindakan yang dilakukan baik secara individu maupun kelompok dengan maksud untuk mencapai tujuan yang telah dirumuskan. Adapun unsur-unsur penerapan meliputi: 1) adanya program yang dilaksanakan; 2) adanya kelompok target, yaitu masyarakat yang menjadi sasaran dan diharapkan akan menerima manfaat dari program tersebut; 3) adanya pelaksanaan, baik organisasi atau perorangan yang bertanggung jawab dalam pengelolaan, pelaksanaan maupun pengawasan dari proses penerapan tersebut. (Lukman Ali, 1995:1044).

\section{a. Konsep dan Definisi Tanggung Jawab Sosial Perusahaan (Corporate Social Responsibilty)}

Sebelum membahas mengenai kewajiban CSR bagi perusahaan, terlebih dahulu dipahami mengenai definisi-definisi dan konsep CSR tersebut. Konsep CSR sebenarnya relatif baru, bahkan dalam teori korporasi klasik, akar-akar konsep CSR sulit ditemukan. Namun demikian persoalan CSR jika dicari akar teoritisnya, konsep CSR mendapat pijakan yang relatif kuat karena dua perkembangan berikut ini;

Pertama, dalam realitasnya agen pemerintah tidak bisa selamanya menjalankan kesejahteraan masyarakat secara memuaskan. Kedua, pasar terkadang gagal mengalokasikan sumber daya secara efisien. (Sofyan Djalil, 2003:4). Hal itu terjadi apabila, salah satu tindakan agen pasar, ternyata menimbulkan dampak bagi kesejahteraan atau kondisi pihak lainnya.

Sayangnya, dampak ini terkadang tidak diperhatikan oleh agen yang bersangkutan. Kegiatan ekonomi atau perusahaan seyogyanya dapat memberikan dampak positif bagi perubahan masyarakat di lingkungan masyarakat itu sendiri. 
Perubahan tersebut tentunya dilandasi oleh kemauan yang tulus yang lahir dari dalam diri pelaku usaha/perusahaan. Hal ini tentunya bertujuan pengelolaan sumber daya ekonomi dan sosial dalam pelaksanaannya menunjang pembangunan yang stabil dengan syarat utama yaitu efisien dan pemerataan. (Sofyan Djalil, 2003:4).

Semakin berkembangnya penerapan CSR ini, maka banyak konsep yang muncul yang diungkapkan berbagai pihak mengenai konsep ini. Salah satu yang terkenal adalah konsep triple bottom line yang dikemukakan oleh John Elkington, ia memberi pandangan bahwa jika sebuah perusahaan ingin mempertahankan kelangsungan hidupnya, maka perusahaan tersebut harus memperhatikan "3P". Selain mengejar keuntungan (profit), perusahaan juga harus memperhatikan dan terlibat pada pemenuhan kesejahteraan masyarakat (people) dan turut berkontribusi aktif dalam menjaga kelestarian lingkungan (planet). (Gunawan Widjaja dan Yeremia Ardi Pratama, 2008:33). Kemudian Hendeberg mengadaptasi konsep ini dan membuat model penerapan CSR yang bernama Hendeberg Pyramid's sebagai bentuk strategi perusahaan dalam menerapkan CSR. (Dwi Endah Manurung, 2012: 22).

Garriga dan Mele memetakan konsep-konsep mengenai CSR. Dalam kesimpulannya, Garriga dan Mele menjelaskan CSR mempunyai fokus pada 4 (empat) aspek utama, yakni; pertama, mencapai tujuan untuk mendapatkan keuntungan yang berkelanjutan, kedua, menggunakan kekuatan bisnis secara bertanggung jawab, ketiga, mengintegrasikan kebutuhan-kebutuhan sosial, dan keempat berkontribusi ke dalam masyarakat dengan melakukan hal-hal yang beretika. Secara praktis dapat dikelompokan ke dalam empat kelompok teori yang berdimensi profit, politis, sosial dan nilai-ilai etis. (Teddy Lesmana http://mediaindonesia.com).

Konsepsi mengenai CSR pertama kali diperkenalkan oleh Howard Bowen melalui bukunya yang berjudul "Social Responsibility of the Businessman". Melalui karyanya tersebut, Howard Bowen diberi gelar sebagai Bapak dari CSR (Father of CSR). (Jeremy Moon dan David Vogel, tth: 304) Dalam konteks global, sementara ini tidak terdapat kesatuan definisi mengenai CSR. (Price Waterhouse Coopers, tth:7). Kalaupun terdapat definisi CSR, pengertian tersebut dapat dipandang bersifat tentative definition. The European Commission memaknai CSR sebagai as a concept whereby companies integrate social and environmental concerns in their business operations and in their interactions with stakeholders on a voluntary basis. (Stephen Brammer, Gregory Jackson dan Dirk Matter, 2012:5).

Konsep CSR di Indonesia sebenarnya bukan hal yang baru karena CSR sudah dikenal dan dipraktekan di Indonesia sekitar tahun 1970-an. Berdasarkan pengertiannya yang klasik CSR masih dipersepsikan sebagai ideologi yang bersifat amal (charity) dari pihak pengusaha kepada masyarakat di sekitar tempat 
beroperasinya perusahaan. Disamping itu masih banyak pihak yang mengidentikkan CSR dengan Community Development (CD).

CSR tidak dapat disederhanakan hanya sebatas Community Development (CD) karena sesungguhnya secara historis keberadaan CD dan CSR sangat berbeda. CD merupakan kerelaan perusahaan berbentuk benefit bagi masyarakat di sekitar lokasi perusahaan, sedangkan CSR muncul sebagai sebuah reaksi atas tuntutan masyarakat yang didasarkan pemikiran bahwa keberadaan perusahaan di suatu tempat akan dan niscaya mengurangi hak-hak masyarakat setempat. CSR mensyaratkan sesuatu yang lebih dari sekedar memberikan berbagai bantuan kepada masyarakat di sekitar lokasi usaha.

Definisi CSR secara etimologi di Indonesia kerap diterjemahkan sebagai tanggung jawab sosial perusahaan. Dalam konteks lain, CSR kadang juga disebut sebagai tanggung jawab sosial korporasi, tanggung jawab sosial dunia usaha atau tanggung jawab sosial lingkungan perusahaan. Namun apabila disebut salah satu darinya, konotasinya pastilah kembali kepada CSR. Kendati tidak mempunyai definisi tunggal, konsep ini menawarkan sebuah kesamaan, yaitu kesinambungan antara perhatian terhadap aspek ekonomis dan perhatian terhadap aspek sosial serta lingkungan. (Yusuf Wibisono. 2007:8).

Dengan demikian, CSR dapat diartikan sebagai komitmen perusahaan untuk berperan serta dalam pembangunan berkelanjutan guna meningkatkan kualitas kehidupan dan lingkungan yang bermanfaat, baik bagi perusahaan sendiri, komunitas setempat, maupun masyarakat pada umumnya. Rumusan atau definsi atau pengertian yang diberikan di atas menunjukkan kepada masyarakat bahwa setidaknya ada 3 (tiga) hal pokok yang membentuk pemahaman atau konsep CSR. Ketiga hal tersebut adalah:

1) Bahwa sebagai suatu artifical person, perusahaan atau korporasi tidaklah berdiri sendiri dan terisolasi, perusahaan atau perseroan tidak dapat menyatakan bahwa mereka tidak memiliki tanggung jawab terhadap keadaan ekonomi, lingkungan, maupun sosialnya.

2) Keberadaan (eksistensi) dan keberlangsungan (sustainability) perusahaan atau korporasi sangatlah ditentukan oleh seluruh stakeholders-nya dan bukan hanya shareholders-nya. Para stakeholders ini, terdiri dari shareholders, konsumen, pemasok, klien, customer, karyawan dan keluarganya, masyarakat sekitar dan mereka yang terlibat baik secara langsung maupun tidak langsung dengan perusahaan (the local community and society at large). (Bismar Nasution, 2011:12).

Melaksanakan CSR berarti juga melaksanakan tugas dan kegiatan seharihari perusahaan atau korporasi, sebagai wadah untuk memperoleh keuntungan melalui usaha yang dijalankan dan atau dikelola olehnya. Jadi, CSR berarti juga menjalankan perusahaan atau korporasi untuk memperoleh keuntungan. 
Berdasarkan perspektif teoritik, pada tahun 1979 Archie Caroll memperkenalkan teori "the Four-Part Model of Corporate Social Responsibility". Teori yang dibangun oleh Caroll tersebut meyakini CSR sebagai konsep multi-lapis, yang dapat dibedakan menjadi empat aspek (yang saling berhubungan) yakni tanggung jawab filantropi, etis, hukum dan ekonomi.

Keempat aspek tanggungjawab tersebut diilustrasikan dalam sebuah piramida yang masing-masing tanggung jawab berada dalam sebuah lapisan yang berurutan. (Judith Hennigfeld, Manfred Pohl dan Nick Tolhurst, 2006:5-8). Dalam konteks ini dapat dipahami bahwa CSR dapat dipandang dari aspek hukum (legal), walaupun sejatinya aspek hukum dari CSR akan selalu terikat dengan ketiga aspek lainnya.

Berdasarkan pengertian yang lebih luas CSR dipahami sebagai konsep yang lebih "manusiawi" di mana suatu organisasi dipandang sebagai agen moral. Oleh karena itu, dengan atau tanpanya hukum, sebuah organisasi bisnis harus menjunjung tinggi moralitas. (Fajar Nursahid, 2006:5). Di Indonesia sendiri CSR dimaknai sebagai kewajiban hukum, dengan diatur secara khusus di dalam peraturan perundang-undangan yang mewajibkan setiap perusahaan untuk melaksanakan CSR. Sebagai kewajiban hukum maka perusahaan harus mematuhi aturan yang ada pada hukum tersebut tanpa terkecuali. Selain itu CSR oleh perusahan harus dimaknai sebagai suatu kebutuhan bagi perusahaan dalam menjalankan kegiatan usahanya.

Pembicaraan mengenai CSR dari perspektif hukum, maka tentu akan berkenaan dengan tanggungjawab hukum (legal responsibility). Dengan demikian CSR dilihat sebagai bagian dari tanggung jawab hukum atau tanggung jawab yang didasarkan atas hukum. menurut Archie Caroll: "Legal responsibility. The legal responsibility of corporations demands that businesses abide by the law and 'play by the rulesof the game'. Laws are understood as the codification of society'smoral views, and therefore abiding by these standards is a necessaryprerequisite for any further reasoning about social responsibilities. In some sense, one might consider legal responsibility as a truism, which corporations have to fulfil just to keep their licence tooperate. However, one only needs to open the business pagesnowadays to see that the ongoing coverage of corporate scams,scandals and lawsuits reveals that abiding by the law, not bendingthe rules and not cutting corners, can hardly be taken for grantedin today's business world. As with economic responsibilities" (Judith Hennigfeld, Manfred Pohl dan Nick Tolhurst, 2006:7).

Pandangan Caroll diatas memberikan pemahaman, adalah tanggungjawab hukum dari sebuah perusahaan atau korporasi untuk menyelenggarakan kegiatan/aktivitas bisnisnya sesuai dengan hukum dan bermain sesuai aturan yang telah ditetapkan oleh Pemerintah. Hukum yang ditetapkan tersebut dipahami sebagai pandangan moral masyarakat yang dikodifikasikan (the codification of society's moral view). 
Dengan beranjak pada apa yang disampaikan Carol, hakikatnya apabila CSR dipandang dari sudut (tanggung jawab) hukum maka seyogyanya tidak dimaknai sebatas suatu kebenaran yang dijalankan oleh perusahaan hanya sebagai syarat untuk menjaga kelangsungan izin operasi perusahaan saja atau sekedar memenuhi tuntutan peraturan perundang-undangan yang berlaku melainkan CSR merupakan sebuah kebutuhan seluruh perusahaan dalam rangka memenuhi tanggung jawab sosial. Tanggung jawab hukum dari perusahaan untuk menyelenggarakan kewajiban CSR tentu berimplikasi pada perbincangan mengenai landasan hukum diberlakukannya CSR itu sendiri dalam bingkai hukum di Indonesia.

\section{b. Undang-Undang Nomor 40 Tahun 2007 tentang Perseroan Terbatas}

Penerapan atau pelaksanaan CSR (Corporate Social Responsibility) di Indonesia diatur di dalam Undang-Undang Nomor 40 Tahun 2007 tentang Perseroan Terbatas (UUPT). Pengaturan CSR atau tanggung jawab sosial dan lingkungan perusahaan dalam Pasal 74 UUPT menimbulkan ketidakkonsistenan dengan ketentuan sebelumnya yakni Pasal 1 angka 3 UUPT yang menyebutkan bahwa "Tanggung Jawab Sosial dan Lingkungan adalah komitmen perseroan untuk berperan serta dalam pembangunan ekonomi berkelanjutan guna meningkatkan kualitas kehidupan dan lingkungan yang bermanfaat, baik bagi perseroan sendiri, komunitas setempat, maupun masyarakat pada umumnya".

Hal ini terlihat dari adanya perbedaan konsep dasar terhadap tanggung jawab sosial dari yang semula bersifat social responsibility (moral obligation), sebagaimana tercantum dalam Pasal 1 angka 3 UUPT, menjadi "kewajiban hukum" (legal obligation) dalam Pasal 74 UUPT secara eksplisit menegaskan adanya kewajiban bagi perusahaan untuk melaksanakan tanggung jawab sosial dan lingkungan serta pengenaan sanksi bagi perseroan yang tidak melaksanakannya.

Ketentuan mengenai CSR diatur dalam Pasal 74 Undang-Undang Nomor 40 Tahun 2007 yang menentukan bahwa; Perseroan yang menjalankan kegiatan usahanya di bidang dan/atau berkaitan dengan sumber daya alam wajib melaksanakan Tanggung Jawab Sosial dan Lingkungan, Tanggung Jawab Sosial dan Lingkungan sebagaimana dimaksud pada ayat (1) merupakan kewajiban Perseroan yang dianggarkan dan diperhitungkan sebagai biaya Perseroan yang pelaksanaannya dilakukan dengan memperhatikan kepatutan dan kewajaran.

Perseroan yang tidak melaksanakan kewajiban sebagaimana dimaksud pada ayat (1) dikenai sanksi sesuai dengan ketentuan peraturan perundangundangan. Ketentuan lebih lanjut mengenai Tanggung Jawab Sosial dan Lingkungan diatur dengan Peraturan Pemerintah. Pasal 74 ayat (1) UUPT tersebut menentukan bahwa perseroan yang menjalankan kegiatan usahanya di bidang dan/atau berkaitan dengan sumber daya alam wajib melakukan tanggung jawab sosial dan lingkungan. 
Kata "perseroan" tersebut mengacu pada badan hukum seperti yang dijelaskan dalam Pasal 1 ayat (1) UUPT yaitu perseroan terbatas yang selanjutnya disebut perseroan adalah badan hukum yang merupakan persekutuan modal, didirikan berdasarkan perjanjian, melakukan kegiatan usaha dengan modal dasar yang seluruhnya terbagi dalam saham dan memenuhi persyaratan yang ditetapkan dalam undang-undang ini serta peraturan pelaksanaannya.

Pengertian perseroan tersebut seharusnya yang wajib melaksanakan CSR adalah semua perseroan yang berbadan hukum, bukan hanya perusahaan yang bergerak dan berkaitan dengan sumber daya alam saja, tetapi apabila mengarah pada Pasal 74 ayat (1) UUPT, perseroan yang wajib melaksanakan CSR adalah hanya dibatasi pada perseroan yang kegiatan usahanya bergerak dan/atau berkaitan dengan sumber daya alam. Maksud dari kalimat tersebut adalah diterangkan dalam penjelasan Pasal 74 ayat (1) UUPT yaitu, perseroan yang menjalankan kegiatan usahanya dibidang sumber daya alam adalah perseroan yang mengelola dan memanfaatkan sumber daya alam. Sedangkan perseroan yang menjalankan kegiatan usahanya yang berkaitan dengan sumber daya alam adalah perseroan yang tidak mengelola dan tidak memanfaatkan sumber daya alam, tetapi kegiatan usahanya berdampak pada fungsi kemampuan sumber daya alam.

Pasal 74 ayat (2) menentukan bahwa tanggung jawab sosial dan lingkungan sebagaimana yang dimaksud pada ayat (1) merupakan kewajiban perseroan yang dianggarkan dan diperhitungkan sebagai biaya perseroan yang pelaksanaannya dilakukan dengan memperhatikan kepatutan dan kewajaran. Biaya perseroan yang dimaksud disini adalah berupa penyisihan sebagian keuntungan yang dianggarkan perseroan sebagai wujud kesadaran perusahaan bahwa nasib perusahaan tersebut tergantung juga pada kondisi lingkungan dan masyarakat sekitar. Jika dilihat dari keuntungan yang didapat perusahaan yang menerapkan CSR, perusahaan bukan saja berhasil melestarikan lingkungan dan membantu masyarakat sekitar, namun juga ikut membantu perusahaan itu sendiri dalam bentuk investasi jangka panjang.

Pasal 74 ayat (2) UUPT tersebut yang masih dipertanyakan adalah katakata "kepatutan dan kewajaran". Kata-kata "kepatutan dan kewajaran" tersebut tidak dapat didefinisikan secara tepat, sebab ukuran dari sesuatu yang patut dan wajar sangatlah subjektif. Perusahaan bisa saja melakukan CSR yang kurang berguna atau mutunya tidak sebanding dengan kemampuan perusahaannya. Apabila perusahaan tersebut adalah perusahaan yang berskala multi-nasional, maka seharusnya perusahaan tersebut dapat menerapkan CSR yang lebih baik dari CSR yang sudah dilakukan perusahaan tersebut. Sehingga kata-kata "kepatutan dan kewajaran" ini dapat mengakibatkan ketidakpastian mengenai standarisasi pelaksanaan program CSR yang harus dilakukan perusahaan.

Pasal 74 ayat (3) UUPT menentukan adanya sanksi hukum sesuai dengan ketentuan peraturan perundang-undangan bagi perseroan yang tidak melaksanakan CSR, ini berarti bahwa perusahaan yang tidak menerapkan CSR 
akan dikenakan sanksi yang diatur dalam peraturan perundangan-undangan yang terkait. Sanksi bagi perusahaan yang tidak melaksanakan CSR tidak diatur dalam UUPT tetapi merujuk pada peraturan perundang-undangan lain yang terkait. Ketentuan tersebut merujuk kepada Undang-Undang Nomor 25 Tahun 2007 tentang Penanaman Modal (UUPM).

Ketentuan lebih lanjut mengenai CSR dalam undang-undang ini diatur dengan Peraturan Pemerintah (Pasal 74 ayat (4) UUPT). Rumusan Pasal 74 ayat (3) tersebut telah menegaskan bahwa CSR dinyatakan sebagai kewajiban dalam makna liability, mau tidak mau harus ada sanksi bagi perusahaan yang tidak melaksanakannya. Permasalahannya adalah UUPT tidak mengatur sanksi baik dari aspek perdata, pidana maupun administrasi, termasuk juga sanksi bagi perusahaan yang tidak melaksanakan CSR. Hal ini berbeda dengan UUPM yang mengatur mengenai sanksi bagi investor yang tidak melakukan kewajibannya. Demi adanya kepastian dan kepatuhan hukum, pemerintah seharusnya merumuskan suatu sanksi apabila ada perusahaan tidak melaksanakan CSR.

\section{c. Peraturan Pemerintah Nomor 47 Tahun 2012 tentang Tanggung Jawab Sosial Lingkungan Perseroan Terbatas}

Dengan diterbitkannya Peraturan Pemerintah Nomor 47 tahun 2012 tentang Tanggung Jawab Sosial dan Lingkungan, pemerintah seakan kembali menguatkan bahwa Perusahaan wajib menjadikan CSR sebagai bagian operasional bisnisnya dan harus menyisihkan sebagian anggaran perusahaan untuk melaksanakan program CSR. PP No. 47 Tahun 2012 yang mengatur tentang Pelaksanaan Tanggung Jawab Sosial dan Lingkungan adalah tindak lanjut atau merupakan aturan turunan dari Pasal 74 ayat (4) UUPT yang mengatur mengenai CSR. Peraturan Pemerintah ini adalah sebagai peraturan perundang-undangan sebagai peraturan pelaksana dari Pasal 74 UUPT.

Berdasarkan Pasal 2 PP No. 47 Tahun 2012 menentukan bahwa, "Setiap Perseroan selaku subjek hukum mempunyai tanggung jawab sosial dan lingkungan". Pasal ini bertentangan dengan Pasal 74 ayat (1) UU No. 40 Tahun 2007, yaitu disebutkan bahwa : "Perseroan yang menjalankan kegiatan usahanya di bidang dan/atau berkaitan dengan sumber daya alam wajib melaksanakan Tanggung Jawab Sosial dan Lingkungan", dapat dilihat bahwa dalam pembuatan peraturan terjadi ketidakkonsistenan antara UU dengan peraturan pelaksananya, hal ini menimbulkan pertentangan, yaitu Peraturan Pemerintah (PP) sebagai peraturan pelaksana bertentangan dengan Undang-Undang diatasnya. UUPT mengatur bahwa yang mempunyai kewajiban dalam melaksanakan tanggung jawab sosial dan lingkungan hanya Perseroan yang menjalankan kegiatan usahanya di bidang dan/atau berkaitan dengan sumber daya alam saja, sedangkan di dalam PP menyatakan setiap perusahaan selaku subjek hukum mempunyai 
tanggung jawab sosial dan lingkungan. Kata "mempunyai" disini menggambarkan suatu kewajiban yang harus dipenuhi.

Kemudian Pasal 3 ayat (1) PP No. 47 Tahun 2012, disebutkan bahwa: "Tanggung jawab sosial dan lingkungan sebagaimana dimaksud dalam Pasal 2 menjadi kewajiban bagi Perseroan yang menjalankan kegiatan usahanya di bidang dan/atau berkaitan dengan sumber daya alam berdasarkan Undang-Undang". Jadi apabila merujuk pada Pasal ini bahwa terdapat ekstensi/perluasan makna kata bahwa bukan hanya perusahaan yang melakukan kegiatan usaha yang berkaitan dengan sumber daya alam saja yang mempunyai kewajiban melaksanakan tanggung jawab sosial dan lingkungan namun setiap perseroan selaku subjek hukum juga mempunyai kewajiban dalam melaksanakan tanggung jawab sosial dan lingkungan.

Kemudian ayat (2) disebutkan bahwa: "Kewajiban sebagaimana dimaksud pada ayat (1) dilaksanakan baik di dalam maupun di luar lingkungan Perseroan". Dengan demikian sudah jelas bahwa dalam melaksanakan tanggung jawab sosial dan lingkungan dilakukan baik di dalam perusahaan maupun di luar perusahaan. Kewajiban tersebut dalam melaksanakannya diatur dalam Pasal 4 ayat (1) dan (2) yaitu dilaksanakan oleh Direksi berdasarkan rencana kerja tahunan perseroan setelah mendapatkan persetujuan dari Dewan Komisaris atau RUPS, sesuai dengan anggaran dasar Perseroan, kecuali ditentukan lain dalam peraturan perundangundangan. Rencana kerja yang dimaksud adalah rencana kerja kegiatan dan anggaran yang dibutuhkan dalam pelaksanaan tanggung jawab sosial dan perusahaan dan hal ini diperjelas dalam Pasal 5 ayat (1) dan (2) yaitu, bahwa dalam menjalankan usahanya dibidang dan/atau berkaitan dengan sumber daya alam, dalam menyusun dan menetapkan rencana kegiatan dan anggaran harus memperhatikan kepatutan dan kewajaran yang realisasi anggarannya dilaksanakan oleh perseroan yang diperhitungkan sebagai biaya perseroan.

Seperti yang telah diatur dalam Pasal 6 menentukan bahwa bahwa: "Pelaksanaan tanggung jawab sosial dan lingkungan dimuat dalam laporan tahunan Perseroan dan dipertanggungjawabkan kepada RUPS". Kemudian pada Pasal 7 yang disebutkan bahwa: "Perseroan sebagaimana dimaksud dalam Pasal 3 yang tidak melaksanakan tanggung jawab sosial dan lingkungan dikenai sanksi sesuai dengan ketentuan peraturan perundang-undangan". Jadi setiap perseroan yang tidak melaksanakan tanggung jawab sosial dan lingkungan dikenai sanksi, namun sanksi tersebut ketentuannya diatur oleh undang-undang lain tidak diatur dalam UUPT ataupun PP No. 47/2012, melainkan diatur di UUPM.

Mencermati pengaturan kebijakan CSR di atas dapat diambil kesimpulan bahwa pemerintah terlalu terburu-buru dalam mengambil kebijakan terhadap CSR. Pengaturan CSR dalam UUPT belum dapat mewadahi seluruh pemangku kepentingan CSR, baik dari sisi Perusahaan, Pemerintah maupun Masyarakat. Bentuk atau konsep CSR yang berkembang di Amerika belum dapat sepenuhnya di 
pahami oleh pelaku-pelaku CSR di Indonesia, sebagai contoh; di Amerika Serikat, CSR telah berkembang menjadi etika bisnis yang begitu penting dan memberikan tekanan bagi perusahaan-perusahaan untuk mengimplementasikannya. Di Amerika Serikat, terlihat kecenderungan perusahaan-perusahaan yang melihat CSR tidak lagi menjadi kewajiban yang dapat membebani perusahaan, tetapi justu dapat dijadikan sebagai alat atau strategi baru dalam hal pemasaran atau marketing perusahaan. (DC Kurniawan, 2011:8).

Beredar wacana bahwa apabila suatu perusahaan berpartisipasi dalam isuisu sosial, tidak hanya perusahaan tersebut akan kelihatan baik di mata para konsumen, investor, dan analisis keuangan, tetapi perusahaan tersebut akan memiliki reputasi yang baik di mata congress, atau bahkan di dalam ruang pengadilan apabila terlibat dalam suatu perkara. (Bismar Nasution http://bismar.wordpress.com/aspek-hukum-tanggung-jawab-sosial.html).

Istilah CSR memang baru belakangan ini marak dikenal oleh kalangan pebisnis di Indonesia, yaitu pada dekade awal 2000an. Undang-Undang Nomor 1 Tahun 1995 tentang Perseroan Terbatas (UUPT terdahulu) belum mengenal istilah CSR. CSR baru diatur pada UU No. 40 Tahun 2007 UUPT. Dalam hal pengaturan UUPT masih dinilai abstrak dan tidak secara komprehensif mengatur mengenai CSR, bahkan terjadi ketidakkonsistenan dan tumpang tindih dengan peraturan perundang-undangan lainnya seperti UU BUMN dan UUPM.

Menurut Peter Mahmud Marzuki dalam perkuliahannya mengatakan, "CSR di Indonesia berbeda jauh dari CSR yang ada di Amerika Serikat. CSR di Amerika merupakan alat untuk mengalihkan pembayaran pajak, sehingga ini menjadi keuntungan tersendiri bagi perusahaan, namun di Indonesia CSR yang telah diwajibkan dan telah dilaksanakan tetap tidak menghilangkan kewajiban perusahaan untuk membayar pajak". (Peter Mahmud Marzuki, tth.).

Pengaturan kebijakan CSR di Indonesia terkesan hanya mentransplantasi kebijakan CSR yang ada di dunia barat (Amerika Serikat) tanpa melihat kemanfaatan apa yang akan diperoleh bagi tiap pihak, utamanya perusahaan dan masyarakat. Aturan hukum hanya mewajibkan perusahaan untuk melaksanakan CSR dan tidak memberikan reward atau penghargaan yang sepadan kepada perusahaan. Hal ini mengakibatkan perusahaan yang telah melaksanakan CSR menekan masyarakat untuk membalas budi atas apa yang telah perusahaan berikan kepada masyarakat. Dampaknya terjadi hubungan vertikal antara perusahaan dan masyarakat, perusahaan seakan-akan mempunyai kekuasaan atas masyarakat yang telah menerima CSR nya.

Pengaturan CSR seperti dipaksakan untuk hadir pada UUPT, hal ini mencerminkan pembangunan hukum yang tidak baik bagi Indonesia. Sajtipto Rahardjo berpendapat, pembangunan hukum harus memiliki makna ganda. Pertama, sebagai suatu usaha untuk memperbaharui hukum positif sendiri, sehingga sesuai dengan kebutuhan untuk melayani masyarakat pada tingkat 
perkembangannya yang mutakhir. Kedua, sebagai usaha untuk memfungsionalkan hukum dalam masa pembangunan, yaitu dengan cara turut mengadakan perubahan-perubahan sosial sebagaimana dibutuhkan oleh masyarakat yang sedang membangun. (Satjipto Rahardjo, 2009:203).

\section{PENUTUP}

Tanggung jawab sosial perusahaan atau corporate social responsibility (CSR) adalah istilah yang baru dikenal belakangan ini di Indonesia, yaitu dekade 2000an. Undang-Undang Nomor 1 Tahun 1995 tentang Perseroan Terbatas belum mengenal istilah CSR. CSR baru diatur pada UU No. 40 Tahun 2007 UUPT. Dalam hal pengaturan UUPT masih dinilai abstrak dan tidak secara komprehensif mengatur mengenai CSR, bahkan terjadi ketidakkonsistenan dan tumpang tindih dengan peraturan perundang-undangan lainnya seperti UU BUMN dan UUPM. Penerapan atau pelaksanaan CSR (Corporate Social Responsibility) di Indonesia yang diatur dalam UUPT berdasarkan Pasal 74 UUPT juga menimbulkan ketidakkonsistenan dengan ketentuan sebelumnya yakni Pasal 1 angka 3 UUPT. Hal ini terlihat dari adanya perbedaan konsep dasar terhadap tanggung jawab sosial dari yang semula bersifat social responsibility (moral obligation), sebagaimana tercantum dalam Pasal 1 angka 3 UUPT, menjadi "kewajiban hukum" (legal obligation) dalam Pasal 74 UUPT. Tidak diaturnya ketentuan mengenai sanksi bagi yang tidak menerapkan CSR juga memberikan ketidakpastian hukum dalam pelaksanaan CSR. Begitu juga dengan subjek perusahaan yang diwajibkan dalam UUPT dan PP No. 47 tahun 2012 memiliki perbedaan, sehingga berakibat adanya ketidakpastian secara hukum.

\section{DAFTAR PUSTAKA}

\section{A. Buku}

Ali, Lukman, Kamus Besar Bahasa Indonesia Jakarta: Balai Pustaka, 1995.

Budi Untung, Corporate Social Responsibility, Jakarta: Sinar Grafika, 2008.

Badudu, Yus dan Muhammad Zain, Sultan, Kamus Umum Bahasa Indonesia, Pustaka Sinar Harapan, 1994.

Coopers, Price Waterhouse Coopers, Handbook on Corporate Social Responsibility in India, Price waterhouse Coopers Limited (PwC), India, tth.

Hennigfeld, Judith, Pohl, Manfred dan Tolhurst, Nick, The ICCA Handbook on Corporate Social Responsibility, John Wiley \& Sons, Ltd. England. 2006. 
Moon, Jeremy Moon dan Vogel, David, Corporate Social Responsibility, Goverment and Civil Society, The Oxford Handbook of Corporate Social Responsibility, Oxford University Press, tth.

Ridwan, Juniarso dan Achmad, Sodik Sudrajat, Hukum Administrasi Negara dan Kebijakan Pelayanan Publik, Bandung: Penerbit Nuansa, 2012.

Rahardjo, Satjipto, Membedah Hukum Progresif, Jakarta: Penerbit Kompas, 2006. Hukum dan Perubahan Sosial, Yogyakarta: Genta Publishing, 2009.

Ostas, Daniel T., Decontructing Econstructing Corporate Social Responsibility: Insights from Legal and Economic Theory, Winter, 2001

Wibisono, Yusuf, Membedah Konsep dan Aplikasi CSR, Gresik: Fascho Publishing, 2007.

Widjaja, Gunawan dan Pratama, Yeremia Ardi, Risiko Hukum \& Bisnis Perusahaan Tanpa CSR, Jakarta: Forum Sahabat, 2008.

\section{B. Sumber lain}

Brammer, Stephen, Jackson, Gregory, dan Matter, Dirk, Corporate Social Responsibility and Institutional Theory: New Perspectives on Private Governance, Oxford university Press and Socio-Economic Review, 2012.

Djalil, Sofyan, Kontrak Teoritis dan Praktis Corporate Social Responsibility, Jurnal Reformasi Ekonomi Volume 4 No. 1, Januari-Desember 2003.

C Kurniawan, CSR Dalam Hukum Perusahaan Indonesia, Jurnal Hukum USU, 2011.

Darmadi, Wisnu, 2009, CSR: Kepedulian Perusahaan Terhadap Lingkungan Sekitarnya, http://wisnu.blog.uns.ac.id/2009/11/26/corporate-socialresponsibility/kepedulian-perusahaan-terhadap-lingkungan-disekitarnya/.html

Effendi, Muh. Arief, CSR Melalui Community Development http://wwwsuarakaryaonline.com/news.html?id

Endah Manurung, Dwi, Analisis Penerapan Corporate Social Responsibility (CSR) Pada PT Perkebunan Nusantara IV, Medan, Tesis, Universitas Indonesia, 2012.

ISO 26000: Guidance Standard on Responsibility

Lesmana, Teddy, CSR Untuk Kesejahteran Rakyat, http://media-indonesia.com

Nursahid, Fajar, Praktik Kedermawaan Sosial BUMN: Analisis Terhadap Kedermaan PT. Krakatau Steel, PT. Pertamina dan PT. Telekomunikasi Indonesia, Jurnal Galang Volume 1 No. 2, Januari 2006.

Nasution, Bismar, Aspek Hukum Tanggung Jawab Sosial Perusahaan, Jurnal Hukum Universitas Sumatera Utara, 2011

$$
\text { Aspek Hukum Tanggung Jawab Sosial }
$$

(http://bismar.wordpress.com/aspek-hukum-tanggung-jawab-sosial.html) 


\section{PEDOMAN PENULISAN JURNAL PRANATA HUKUM}

1. Naskah bersifat orisinil, baik berupa hasil riset atau tinjauan atas suatu permasalahan hukum yang berkembang di masyarakat (artikel lepas), dimungkinkan juga tulisan lain yang dipandang memberikan kontribusi bagi pengembangan ilmu hukum.

2. Penulisan terdiri atas beberapa bab penulisan hasil penelitian terdiri dari 3BAB,yaitu ;

BAB I. PENDAHULUAN (Latar Belakang dan Rumusan Masalah) BAB II. PEMBAHASAN (Kerangka Teori dan Analisis), dan BAB III. PENUTUP (Kesimpulan dan Saran).

3. Tulisan menggunakan bahasa indonesia maupun bahasa inggris yang memenuhi kaidah bahasa yang baik dan benar,tulisan menggunakan bahasa indonesia disertai abstrak dalam bahasa inggris (200 kata) dan Kata kunci, ketentuan ini berlaku sebaliknya.

4. Setiap kutipan harus menyebutkan sumbernya, dan ditulis pada akhir kutipan dengan memberi tanda kurung (bodynote). Sumber kutipan harus memuat nama pengaran, tahun penerbitan dan halaman .Contoh : satu penulis (Bagir Manan, 1994: 20), Dua Penulis (Jimly Asshidiqqie dan M.Ali Syafa'at, 2005: 11), Tiga atau lebih penulis menggunakan ketentuan et.al (dkk). Untuk artikel dari internet dengan susunan: nama penulis, judul tulisan digaris bawah, alamat website, waktu download/unduh.

5. Naskah harus disertai dengan daftar pustaka atau referensi ,terutama yang digunakan sebagai bahan acuan langsung. Daftar pustaka dan referensi bersifat alfabetis dengan format; nama pengarang, judul buku, nama penerbit, kota terbit, dan tahun penerbitan. Contoh: Bagir Manan, Hubungan Antara Pemerintah Pusat dan Daerah Menurut UUD 1945, Pustaka Sinar Harapan, Jakarta, 1994.

6. Panjang tulisan antara 15-25 halaman, font times new roman dengan 1,15 spasi. Dalam hal hal tertentu berlaku pengecualian panjang tulisan.

7. Naskah disertai nama lengkap penulis, alamat e-mail dan lembaga tempat berafiliasi saat ini, dan hal lain yang dianggap penting. 


\section{Jurnal PRANATA HUKUM dimaksudkan sebagai}

media komunikasi, edukasi, dan informasi ilmiah bidang ilmu hukum khususnya, dan ilmu sosial pada umumnya. Sajian dan kemasan diupayakan komunikatif melalui bahasa ilmiah.

Redaksi mengundang semua elemen masyarakat baik civitas akademika, praktisi, lembaga masyarakat, maupun perorangan yang berminat terhadap bidang hukum untuk berpartisipasi mengembangkan gagasan, wawasan, dan pengetahuan melalui tulisan untuk dimuat dalam jurnal ini.

Melalui PRANATA HUKUM diharapkan terjadi proses pembangunan dan pengembangan bidang hukum sebagai bagian penting dari rangkaian panjang proses memajukan masyarakat bangsa.

Alamat Redaksi

PRANATA HUKUM

Kampus B Universitas Bandar Lampung Jl. ZA Pagar Alam No.89 Labuhan Ratu, Bandar

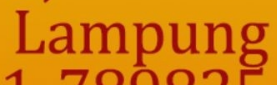

Telp: 0721-789825

Email: jurnal.mh@ubl.ac.id

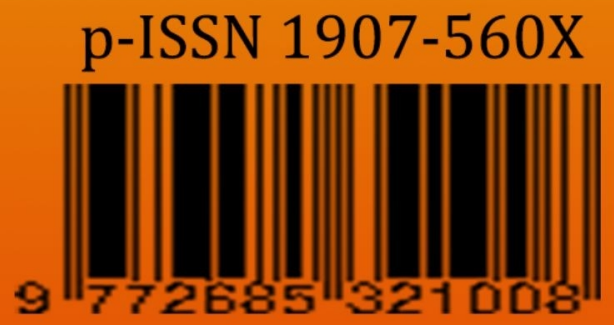

